\title{
Political Regime or State (State-Law) Regime?
}

\section{Vladimir Valentinovich Kozhevnikov}

Department of Theory and History of State and Law, Omsk State University Dostoevsky, Omsk, Russia

Email: kta6973@rambler.ru

\section{Abstract:}

The article emphasizes and substantiates the leading place of the political (state, state-legal) regime in the system of elements of the state form. Attention is paid to the correlation of political, state and state-legal regime, emphasizing that the latter characterizes democratic states.

Keywords:

form of state; political regime; state regime; state and legal regime

\section{Introduction}

We believe that the relevance of this article does not raise any doubts, because it is devoted to one of the structural components of the form of the state, which, as the name of the first one, is called by scientists differently.

\section{Research Methods}

When preparing a scientific article, the following methods were used:

1. General philosophical (dialectical-materialistic), which is used in all social sciences;

2. General scientific (analysis and synthesis, logical and historical, comparisons, abstractions, etc.), which are used not only by the theory of state and law, but also by other social sciences;

3. Special methods (philological, cybernetic, psychological, etc.), developed by special sciences and widely used for the knowledge of state and legal phenomena;

4. Private scientific (formal legal, interpretation of law, etc.), which are developed by the theory of state and law.

\section{Discussion}

\subsection{The Concept of the State (State-Legal) Regime}

In the legal literature, there are several definitions of the political (state, state-legal) regime from the standpoint of the formal legal approach, which differ slightly from each other. The most common idea of it is the definition of it, as a set of means, methods, methods or techniques for exercising state power [1]. It is adjoined by other similar to it, but at the same time, to a certain extent different from it ideas. Among them, one can single out the definition of the state regime of the Soviet theoretical scientist Vladimir Sergeevich Petrov, which the latter interpreted as a specific manifestation of state organization, expressed in the state and nature of democracy and political freedom in society [2]. 
Another closely related to the traditional definition of the state-legal regime can serve as its consideration as a system or set of forms, methods, means and methods of ruling, through which state power legitimizes its existence and functioning [3]. Viktor Dmitrievich Perevalov, using the term \& state-political regime, believes that ... this is a set of methods and ways of exercising state power [4]. From the position of Vladimir Ivanovich Chervonyuk, "the state regime is the methods of exercising political power, the final political state in society, which is formed as a result of the interaction and confrontation of various political forces, the functioning of all political institutions and is characterized by democracy or anti- democracy" [5].

In our opinion, the original interpretation of the political regime is given by Dmitry Alexandrovich Lubnin, who claims that it is "a set of political relations characteristic of a certain type of state, the means and methods used by the authorities, the existing relations between state power and society. dominant forms of ideology, social and class relationships, the state of political culture [6]. Understanding by the form of the state the organization of state power, covering the form of government, the form of state structure and the political regime, the latter is interpreted by Svetlana Vladimirovna Boshno somewhat more broadly, namely: as a system of methods, forms and methods of exercising state power. Moreover, from the standpoint of the author, the concept of a political regime has a meaning both in the narrow sense - a set of methods of state leadership, and in the broad sense of the word - the level of guarantee of democratic rights and political freedoms of the individual, the degree of correspondence of official constitutional legal forms to political realities, the nature of the attitude of power structures to the legal foundations of state and public life [7]. In principle, understanding the state regime in the same way, the team of authors - Valentin Yakovlevich Lyubashits, Andrey Yuryevich, Mordovtsev and Alexey Yuryevich Mamychev, who claims, firstly, that it makes it possible to determine who is the real ruler in the country, what is the set of means and methods, with the help of which they rule over the minds and actions of people; its essential properties are associated with the characteristics of the legal status of the individual; the attitude of the subject of power to society and to the minority that are part of it; the degree of centralization of territorial management; secondly, given the more volatile and mobile nature of the political regime in comparison with the form of government and the form of state structure, they do not deny the position that the former is not considered as an integral part of the form of government, because this category "... is intended for a meaningful analysis of a number of important, internal sides of the political process and in this sense is a certain aspect of the category state content; "The category" political regime "in the proper sense of the word does not mean the actual form of government, not all the listed permanent and temporary factors of political life, but the conditions themselves, the climate in which they exist" [8].

Paying attention to the importance of the political regime, scientists rightly emphasize that it "... is the most dynamic form of the state (or rather, a component of the form of the state - Vladimir Valentinovich Kozhevnikov); "With its change, even if the form of government and the form of state structure remain the same, a change in the course of domestic and foreign policy may follow" [9]. In a review of the monograph by Yuri Alexandrovich Tikhomirov The modern state: continuity, novelty, prospects [10], Sergei Ivanovich Nosov draws particular attention to the fact that, examining the dynamism of political regimes, the author substantiates the important conclusion that they are a sensitive barometer of relations between the state and citizens. With a balance of their interests, the regimes remain stable; when this balance is mixed, stability is lost, as a result of which the regimes also change [11]. 
Defining the state-legal (political) regime as a set of techniques, methods and methods by which state power is exercised, Alexander Yuryevich Larin quite reasonably notes that it is he who points to the substantive aspects of statehood, reveals its essence. At the same time, the scientist defines the form of government and the state structure as the external form of the state, and the political regime as internal [12]. Lyudmila Aleksandrovna Morozova also considers the state-legal regime to be the leading element of the form of the state, since it has a decisive influence on the form of government and state structure [13].

In the literature, in this regard, it is noted that "any changes occurring in the essence of the state are reflected in its state regime, which also affects other structural elements of the form of the state — the form of government and the form of state structure" [14]. Veronika Aleksandrovna Sheremetyeva, agreeing with this provision and referring to the political regime, claims that it "determines the political climate in society"; Determines the dynamics of the development of society and the nature of political power in a given state, its domestic and foreign policy; he ... is associated with constitutional and legal principles and structures that regulate political relations, expressing the interests of the general population [15]. Andrei Aleksandrovich Shanin goes further in this respect, believing that, firstly, it is not enough to associate the political regime only with the form of government and the form of state structure, for the former is closely connected with the essence and content of the state; secondly, it is he who provides not only dynamism, but also a certain stabilization of the political system, bringing its constituent structural elements into an orderly state and interaction, ensuring their interconnection and coordination [16].

Generally speaking, one can agree that assessments of the political regime usually have a symbolic meaning and therefore allow you to create an image of the country, state, type of government without their specific analysis (absolute, old regime; often just in personified form, named after the head of state - Hussein regime, Hitler regime, etc.) [6]; the political regime is a typological, stylistic and figurative characteristic of the state and society [17]. Without questioning these statements of scientists, it should be borne in mind that the formation of the state- legal regime is influenced by other elements of the form of the state [18].

I think that the relationship between the form of government and the state regime is more significant. In this regard, Vladimir Bogdanovich Doglyad notes that "the analysis of various points of view on this issue brings us very close to the conclusion that it is necessary to consolidate the approach of understanding that the actual relationship between the highest bodies of state power within the framework of the form of government allows us to determine the methods of exercising the highest state power, i.e. that is, it gives its functional characteristics, with the help of which this power is exercised "[19]. Further, the author argues that the form of government is a formalized expression of the essence of the state, and the state regime is a really existing relationship of powers among themselves and acts as a legal and political concretization of the form of government [19]. It seems that the consideration of the state-legal regime as a structural element of the form of the state, interacting with its other parts, corresponds to the position according to which "... it is useless and impossible to consider the political regime separately from all other components of the phenomenon - the form of government and state structure, since only all the three characteristics together make it possible to create the most reliable portrait of a particular state" [20].

Another definition of a political regime can be its consideration as a system of forms, methods and methods of ruling, through which state power legitimizes its existence and functioning [3]. In this case, the regime is compared with the very existence of the institutions of 
state power, its stability and efficiency, and not only with the process, the nature of its functioning. In addition, the political regime is associated with the process of legitimizing state power. In the first approximation, the legitimacy of power presupposes the acceptance and support of its citizens as meeting their ideas of righteousness and justice. A deeper penetration into the essence of the category of legitimation inevitably leads the researcher to consider this phenomenon in close connection with such phenomena as legal and political order, national political and legal mentality, traditions and customs, etc. methodologically, it should be noted that the appeal to the concept of the legitimacy of state power, and therefore to such ethnomental and legal or its other actions and the creation of structures, decision-making, the consent of the majority of the population with the normative acts issued by it, the legal policy pursued, etc., arouses considerable heuristic interest. It is the involvement of legitimacy issues that will noticeably revive the research of nation states, political and state regimes, and will make it possible to bring them as close as possible to modern (globalist and anti-globalization) realities [21]. Note that this approach to defining the concept of a political regime is also supported by other scholars. Thus, Maxim Gennadievich Tirskikh notes that “... legitimacy is of interest due to the fact that not only the state (political) power itself, represented by the totality of state authorities and officials exercising political control, can be legitimate, that is, socially acceptable the state, but also those methods, means, methods of government that this power uses "[22].

We believe that the following provisions of the author deserve attention. First, noting that the political regime needs legitimacy, the author emphasizes that, often perceived as a necessary attribute of power, it is legitimized along with it. Secondly, proceeding from the problem of the legitimacy of the political regime, according to the scientist, "... legitimacy should be understood not as the level of public support for certain methods, means and methods of political governance, but how much society agrees with the use of such methods in relation to it, is it ready to obey the actions of the authorities, to execute political decisions made by the state apparatus [22] Abdul-Nasir Zirarovich Dibirov believes that the category of legitimacy is closely related to the political regime [23], which is defined as a set of concrete historical rights and freedoms of citizens ( subjects), implemented in the normal state of a particular political system [23]. From the standpoint of Nikolai Ignatievich Matuzov and Alexander Vasilyevich Malko, the fundamental aspect of the problem is the legitimization of regimes, i.e. support from citizens, the compliance of this phenomenon with the interests of the people. The legitimacy of a political and legal regime can, according to scientists, be defined as its ability to generate and constantly maintain confidence in itself, agreement that the institutions of this regime meet the true interests of the people, society, and the state. The legitimacy of a political and legal regime presupposes, first, a democratic way of establishing it; secondly, a fair and humane entity; thirdly, the objective essence; fourth, the objective necessity and usefulness for the majority of the population; fifth, clarity and efficiency of functioning, ensuring reliable protection of human rights. Without this, the entire pyramid of power may turn out to be shaky and fragile, devoid of supporting structures, a solid foundation [24].

Alexander Vasilyevich Malko examines the concept of political regime through the prism of the following properties: the degree of people participation in the formation of political power, as well as the very methods of such formation; correlation of human and civil rights and freedoms with the rights of the state; guarantee of the rights and freedoms of the individual; characteristics of the real mechanisms of exercising power in society; the degree to which political power is exercised directly by the people; the position of the media, the degree of publicity in society and the transparency of the state apparatus; the place and role of non-state structures in the political system of society; taking into account the interests of the minority when making political decisions; domination of certain methods (persuasion, coercion, etc.) in 
the exercise of political power; principles of relations between society and government; a measure of political pluralism, including a multiparty system; the existence of real mechanisms for bringing officials to political and legal responsibility, including the highest ones [25].

In contrast to the political state and legal regime existing in a particular country, it is characterized by a wide variety of qualitative characteristics. According to Mikhail Nikolaevich Marchenko, the most important of them are the following: methods and procedure for the distribution of competence between various state bodies and the nature of their relationship; the degree of reality and guarantee of the rights and freedoms of citizens; the role of law in the life of society and in solving public affairs; the place and role in the state mechanism of the army, police, counterintelligence and other structures similar to them; the degree of real participation of citizens and their associations in state and social and political life, in government; the main ways of resolving social and political conflicts arising in society [1]. Nikolai Ignatievich Matuzov and Alexander Vasilyevich Malko believe that the legal regime is an organic part of the state and political regimes. If the state regime is usually defined as a set of methods, techniques, methods of exercising state power, then the political regime is the functional (active) side of the political system of society. The political and state regimes, reflecting the substantive moment of the implementation of managerial decisions, giving political life a certain direction, directly determine the main features, state, general parameters of legal regimes. It is with the help of legal regimes that state and political regimes are practically established and actually implemented, for the latter, as a rule, are clothed in a legal form [24].

\subsection{Other Approaches to the Concept of a Political Regime}

When characterizing the political (state, state-legal) regime, one cannot ignore the socalled political-system approach in its understanding as some expression of the political system of society. A special role in such an understanding of regimes is played by their comparison with the central concept of political science - political power and the political system as the sphere of exercising this power. The correlation of the state regime with political power, political system, political process gives rise to a specific understanding of the regime. So, according to the American political scientist Robert Dahl, a political regime is the organization of political power on the scale of human society, its structuring for specific purposes and using specific methods [26]. In Russian science, the political-system approach gained popularity in the early 90s. XX century.

However, despite this, it is practically not widespread in the theory of state and law. One of the most fundamental political-system definitions can be called the definition proposed by Andrei Pavlovich Tsygankov, interpreting the political regime as a set of certain power structures that function in the general (structural and temporal) framework of the political system of society and pursue the goal of stabilizing it, relying on this on the prevailing (or emerging) social interests and using specific methods [27].

Another approach to defining the concept of regime is called sociological. For example, within the framework of the sociological approach, attention is drawn to its interpretation by Jean-Louis Kermonne, who wrote that "a political regime is understood as a set of elements of an ideological, institutional and sociological order that contribute to the formation of political governance of a given country for a certain period" [28]. So, the supporters of the sociological approach do not rigidly link the political system and the regime, they expand the area of existence of the latter at the expense of elements of the sociological order, that is, the relations between the governing and the governed, the relationship of competing party groups. 
Svetlana Mikhailovna Khomenko believes that, despite different approaches to understanding the essence of the political and legal regime, it seems possible to single out several of its main parameters, i.e. criteria that characterize its specificity: 1) The nature of the struggle for political leadership: open (free competition in elections), closed (change of leadership is carried out through co-optation, inheritance or violent seizure of power), intermediate (the presence of a tamed opposition adapted to the regime); 2). The level of political participation of the population: narrow (rule of the few and the exclusion of the masses from political life) or wide (ensuring the majority of the population the opportunity to influence political decisions); 3 ). Values and priorities of political leadership: conservatism, reformism, adaptability (with the preservation of the privileges of the ruling elite), revolutionary (radicalism); 4).

Features of the legal institutionalization of political interests and the corresponding forms and methods of exercising power, the specifics of legal regulation of the public administration system: usually the traditional or patriarchal method (fixation occurs at the level of legitimate national customs and traditions), religious and legal (in countries where law is actually one of the sides of the national religion), legislative (consolidation of the will of those in power occurs mainly in normative legal acts: the Constitution, laws, bylaws), a mixed (convergent) mechanism of legal institutionalization (in transitional states, a combination, convergence of various methods of legal formalization, in socialist states, in addition to legislative mechanisms, ideological institutions play a huge role, etc.) [21].

Recognizing the presence of a rational element both in the formal and in the politicalsystemic definition of political regimes, Maxim Gennadievich Tirskikh considers this to be insufficient to determine the object under study. Criticizing these two approaches, the author writes that when interpreting a political regime as a set of methods, means, methods of government (formal approach), the manifestation of regimes and their role in the political, social, and economic life of society is not taken into account. With a political-system approach, characterizing a given state-legal phenomenon as a state of the political system of society, for which a certain balance of forces is inherent between the subjects of this system (political parties, elites, groups of influence, etc.) regarding the exercise of political power and the use of mechanisms of state influence on society, the economic component of the impact of the political regime on society is not affected and such necessary elements of the political regime as methods, means, methods of political management of society are not indicated [29]. Based on this, the author proposes his own, so-called integrative-differentiated approach to understanding the political regime: “... it is an external, dynamic, transformable, territorially isolated expression of the political system of society, an indicator of a certain established (temporarily final) political state of society and relations between the government and society, which manifests itself as a set of methods, methods, means and other mechanisms for the implementation of political power, characterized by the existence of certain political processes, a set of specific political institutions, established relations between power and society, the dominant ideology, social relations, economic components, a certain type of political culture [29].

\subsection{The Political Regime is the Main Element of the Form of the State}

The dominant nature of the political (state, state-legal) regime is determined by the fact that it is he who in the system of elements of the form of the state, occupying a leading place, individualizes the form of national statehood, determines its role and socio-political significance in the state-legal mechanism, characterizes the dynamic, the functional side of the state: how it acts, rules, what political atmosphere it creates in society. Moreover, there is a position according to which the political regime is such a general category, which includes, as its constituent elements, both the form of government and the form of state structure [30]. 


\subsection{Identification of Political and State Regime}

The authors positions on the problem of the relationship between the political and state regimes can be grouped as follows.

The first group is represented by those authors who identify these concepts. For example, Lev Ivanovich Spiridonov, recognizing that the political regime is a characteristic not only and not so much of the state, but of the entire political system, believes that the latter determines the nature of the state not directly, but being imprinted in the peculiarities of the political regime as the content of the political system [32]. So, Ivan Andreevich Ivannikov, speaking about the political regime, believes that it is ... a concrete manifestation of the state organization, expressed in the state and nature of democracy and political freedom in the state [14]. In principle, while agreeing with the proposed interpretation of the state-legal regime, it is difficult to agree with the author, who unreasonably identifies the state and the political system. Viktor Lavrenievich Kulapov and Alexander Vasilyevich Malko do not equally distinguish between political and state regimes, believing that the concept of a political regime is key for the formation of ideas about the main systems of power [33].

\subsection{Intermediate Position on this Issue}

The second group is represented by scientists who occupy an intermediate position on the issue under consideration. For example, Leonid Pavlovich Rasskazov considers the state regime in a narrow sense as a set of methods for exercising state power: in a broad sense, it "... characterizes the atmosphere of all political life, the level of freedom in society, the position of the individual, the development of democratic institutions, the compliance of official constitutional and legal norms with political realities [34].

\subsection{Differentiation of Political and State Regime}

The third, perhaps the most widespread, is represented by those scientists who differentiate the political and state regime. For example, Vitaly Vasilyevich Oksamytny categorically declares that "the basis ... of the state-political regime is a more capacious concept political regime, representing a set of characteristic relationships of political power with state institutions, society and the individual, based on a combination of methods and means implemented by the authorities to achieve their goals "[35]. Veniamin Evgenievich Chirkin stated that, on the one hand, the political regime is a much more multifaceted phenomenon than just an element of the form of the state. It is taking shape in the country not only as a result of the activities of the state and its organs, but also of various public associations, direct mass political actions of the people, and the influence of a certain ideology. The scientist believed that the main thing in him is the substantive characteristic, he cannot be reduced only to an element of the form of the state. The political regime characterizes the state of democracy in the country, the implementation of universal human values in its internal politics, the political climate. This is a much broader concept. than the state regime. However, on the other hand, the scientist draws attention to the fact that these concepts cannot be opposed, because "in a normal situation, the political regime has the same character as the state, because the activity of the state is the core of the political regime" [36].

There is a point of view according to which the state regime, in addition to the form of government and state structure, is a structural element of the form of the state [37].

\section{State Legal Regime}

However, in our opinion, it is more accurate to define the first as state-legal, if we are talking about the form of a democratic state. In justification of this, appropriate arguments 
should be cited, the main of which is the following: on the one hand, "the state regime ... in all its manifestations is regulated by legal acts" [9], on the other hand, "it is impossible to understand the essence of the legal regime even outside the context of political processes and events occurring in a particular country in a particular country" [38]. A similar position was taken by Dzhangir Abbasovich Kerimov and Dmitry Vladimirovich Shumkov, who considered it justified to distinguish between state and state-legal regimes, since, in their opinion, practice indicates that many states carry out their activities outside and even contrary to the law, violate their legislation. From the point of view of the authors, the state-legal regime is a system of legislatively established democratic measures (concrete practical methods, methods of means) used by the state in the implementation of all its activities to manage civil society [39]. Thanks to such a regime, a normal, calm socio-psychological and political atmosphere is established in society, in which the life of society and each of its members is carried out. The state-legal regime, as Maurice Oriou wrote, "increases the power of the nation and at the same time makes it an environment of existence more imbued with freedom and justice; but at the same time the goal of increasing organized power should remain subordinate to the goal of increasing freedom and justice" [40].

\section{Conclusion}

The position seems to be more justified, according to which an element of the form of the state, in addition to the form of government and the form of state structure, should be called not a political regime, but a state one, if we are talking about non-state regimes, and a state-legal one, if we are talking about democratic regimes.

\section{References}

[1]. Marchenko Mikhail Nikolaevich .. Problems of the general theory of state and law: textbook. in 2 volumes. Vol. 1. State. Moscow : Prospect, 2008.Pp. 246, 254.

[2]. Petrov Vladimir Sergeevich. The type and form of the state. L .: Leningrad Publishing House. University, 1967.Pp. 53-54.

[3]. Kireeva Svetlana Alexandrovna. The political regime as an element of the form of the state (theoretical and legal research): author. dis ... candidate of law. Sciences, Saratov: Saratov Academy of Labor, 1997.P. 17.

[4]. Perevalov Viktor Dmitrievich. Theory of state and law: textbook. Moscow : Yurayt, 2012.P. 77.

[5]. Chervonyuk Vladimir Ivanovich. Theory of state and law: textbook. Moscow: INFRA-M, 2006.P. 165.

[6]. Lubnin Dmitry Alexandrovich. Modern views on the essence of the political regime // Power. 2008. No. 7. P.90.

[7]. Boshno Svetlana Vladimirovna. Theory of state and law: textbook), Moscow: Eksmo. Pp. 7980.

[8]. Lyubashits Valentin Yakovlevich, Mordovtsev Andrey Yuryevich, Mamychev Alexey Yuryevich. Theory of state and law: textbook. Rostov n / D: Phoenix, 2010. Pp. 127, 143-144.

[9]. Pevtsova Elena Aleksandrovna, Vazhenin Aleksey Gennadievich. Theory of State and Law: an educational-practical guide to the course \& Theory of State and Law. Rostov n / a: Phoenix, 2005.P 339.

[10]. Tikhomirov Yuri Alexandrovich. The modern state: continuity, novelty, prospects: monograph. Moscow: INFRA-M, 2013. 
[11]. Nosov Sergei Ivanovich. Review of the monograph by Yuri Alekandrovich Tikhomirov The modern state: continuity, novelty, prospects. Moscow : INFRA-M. 2013.320 p. // Journal of Russian Law. 2013. No. 9. P.128.

[12]. Larin Alexander Yurievich. Theory of state and law: textbook. Moscow: Knizhnyi mir, 2011. P.65.

[13]. Morozova Lyudmila Alexandrovna. Theory of state and law: textbook. Moscow: Eksmo, 2007.P. 90.

[14]. Ivannikov Ivan Andreevich. General theory of state and law: textbook. Rostov n/ D: Nauka-Press, 2008. Pp. 93, 104.

[15]. Sherementieva Veronica Alexandrovna. State regime problems of theory and typology // State power and local government. 2011. No. 2. P.6.

[16]. Shanin Andrey Alexandrovich. Political regime: Essence, content and typology: theoretical and legal aspect: abstract of thesis ... candidate of law. Sciences. Volgograd: Vologograd state. un-t, 1999. P. 6.

[17]. Political science: an encyclopedic dictionary / ed. Yuri Ivanovich. Averyanov. Moscow, Moscow Commercial University 1993. P. 296.

[18]. Kireeva Svetlana Alexandrovna. Political regime as an element of the state form: dis. Cand. legal sciences. Saratov. 1997. P. 127.

[19]. Dooglyad Vladimir Bogdanovich. Correlation of the concepts of state regime, political regime\&quot; and form of government\&quot; // Modern science: actual problems of theory and practice. Series Economics and Law\&quot;. 2013. No. 1-2. P.63.

[20]. Lukyanova Elena Anatolyevna, Shablinsky Ilya Georgevich. Authoritarianism and Democracy. Moscow: Mysl, 2018.P. 162.

[21]. Khomenko Svetlana Mikhailovna. The political regime as an element of the form of the state: theoretical, legal and methodological features of the study / Jurist-Jurist, 2010. No. 4. Pp. 79, 80-81.

[22]. Tirskikh Maxim Gennadievich. Legitimation of political regimes // Bulletin of the South Ural State. un-that. Right. 2007. No. 9. Pp. 20, 21.

[23]. Dibirov Abdul-Nasir Zirarovich. The legitimacy of power and the political regime: dis ... doctor. polit. the science. Moscow: Moscow State University. M.V. Lomonosov, 2012.Pp. 11, 271-272.

[24]. Matuzov Nikolai Ignatievich, Malko Alexander Vasilievich. Political and legal regimes: topical aspects // Social sciences and modernity. 1997. No. 1.Pp. 63-64, 70.

[25]. Malko Alexander Vasilievich. Political and legal life of Russia: topical problems: textbook. Moscow: Yurist, 2000. P. 104.

[26]. Dahl Robert. About democracy. Moscow: Aspect Press, 2000. P. 17.

[27]. Tsygankov Andrey Pavlovich. Modern political regimes: structure, typology, dynamics: textbook. Moscow: Interpraks, 1995. P. 18.

[28] Isaev Boris Akimovich. Concept and typology of political regimes // Social and humanitarian knowledge. 2009. No. 3. P.91.

[29.] Tirskikh Maxim Gennadievich. Transformation of Political Regimes: Monograph. Irkutsk, Institute of Legislation and Legal Information, 2006. Pp.20, 37.

[30]. Manov Grigory Naumovich. On the concept of the form of the state // Uch. app. Tajik State University. Vol. IX Proceedings of jurid. f-that. Stalinabad, 1956. Release. 4 P.7.

[31]. Spiridonov Lev Ivanovich. Theory of state and law: textbook. M.: Mozhaisk polygraph plant, 1995. Pp. 40-50.

[32]. Kulapov Victor Lavrentievich, Malko Alexander Vasilievich. Theory of state and law: textbook. Moscow: Norma, 2009.P. 85.

[33]. Rasskazov Leonid Pavlovich. Theory of state and law: textbook. Moscow: Publishing house. House RIOR, 2008.P. 115. 
[34]. Okamytny Vitaly Vasilievich. Theory of state and law: textbook. Moscow: Impe-publish, 2004.P. 274.

[35]. Chirkin Veniamin Evgenievich. State studies: textbook. Moscow: Jurist, 1999.P. 150.

[36]. Kozhevnikov Vladimir Valentinovich. On the problem of the state regime in modern Russia // Modern law. 2017. No. 5. Pp.5-14.

[37]. Radko Timofey Nikolaevich, Lazarev Valery Vasilievich, Morozova Lyudmila Aleksandrovna. Theory of state and law: textbook. Moscow : Prospect, 2012. P.509.

[38]. Matuzov Nikolai Ignatievich, Malko Alexander Vasilievich. Legal regimes: issues of theory and practice // Jurisprudence. 1996. No. 1. P. 17.

[39]. Kerimov Jangir Abbasovich, Shumkov Dmitry Vladimirovich. Fundamentals of the doctrine of law and state: textbook. Moscow : OLMA Media Group, 2008.Pp. 208-209.

[40]. Oriu Maurice. Fundamentals of Public Law: monograph / trans. from French / ed. Evgeny Bronislavovich Pashukanis. Moscow : Kom. acad., 1929. P. 12. 